\title{
Sustainable-value stream mapping to evaluate sustainability performance: case study in an Indonesian furniture company
}

\author{
Sri Hartini ${ }^{1}$, Udisubakti Ciptomulyono ${ }^{2}$, Maria Anityasari ${ }^{2}$, Sriyanto $^{1}$, Darminto Pudjotomo ${ }^{1}$ \\ ${ }^{1}$ Department of Industrial Engineering, Diponegoro University, Indonesia \\ ${ }^{2}$ Department of Industrial Engineering, Institut Teknologi Sepuluh Nopember (ITS), Indonesia
}

\begin{abstract}
Lean manufacturing tools do not consider environmental and societal benefits. The conventional value stream mapping (VSM) methodology examines the economics of a manufacturing line, most of which are in regards to time (cycle time, lead time, change-out time, etc.). Incorporating the capability to capture environmental and societal performance visually through VSMs will increase its usefulness as a tool that can be used to assess manufacturing operations from a sustainability perspective. A number of studies have addressed the extension of VSM to incorporate additional criteria. A vast majority of these efforts have focused on adding energy-related metrics to VSMs, while several other studies refer to 'sustainable' VSM by including environmental performance in conventional VSMs. This research has developed a method for VSM integrated with environment metric and social metric for ensuring sustainable manufacture. The proposed technique is capable of visualizing and evaluating manufacturing process performance from sustainability view point. The capability of proposed technique has been tested by an application study on furniture company. The study provides insights to practitioners to visualize process performance in economic, environment and social metric.
\end{abstract}

\section{Introduction}

The concept of Lean Manufacturing (LM) was pioneered by a Japanese automotive company, Toyota, during 1950's which was famously known as Toyota Production System (TPS). The primary goal of TPS was to reduce the cost and to improve productivity by eliminating wastes or non-value added activities [1-2]. Manufacturing firms operating in the rapidly changing and highly competitive market of the past two decades have embraced the principles of lean thinking. In doing so, they are reorganized into cells and value streams to improve the quality, flexibility, and customer response time of their manufacturing processes [3]. Studies at the operation level concluded that LM was very powerful for increased operational performance on quality [4-5], reduced inventory [6], productivity [4]; [7], and reduced cost [8 9]. Even LM can also be used as a strategy to improve business performance in terms of profitability [4], sales, customer satisfaction and business performance [10]. But, traditional lean manufacturing tools do not take into account for environmental and societal benefits [11].

During the recent days, the modern manufacturing systems are expected to be lean and sustainable. Lean concepts ensure waste elimination and cost reduction. Sustainable concepts focus on the development of environmentally friendlier products and processes considering the economical and societal constraints as well. There is a potential to extend lean tools for ensuring sustainable benefits.
Few studies have been reported on the context of applying lean tools for developing greener processes and strategies for environmentally benign manufacturing. There is positive impact of integration lean and sustainable manufacturing on three bottom line performance [12]. Value stream mapping (VSM) is a fundamental lean technique to identify waste and value improvement opportunities. VSM is a diagnostic technique that originated from lean manufacturing principles. Its purpose is to identify value-adding and nonvalue-adding activities in the value stream so that wasteful activities can be eliminated, and production can be aligned with demand [13].

It has been emphasized that traditional VSM framework does not account for environmental and societal performance. A number of studies have addressed the extension of VSM to incorporate additional criteria. A vast majority of these efforts have focused on adding environment and energy-related metrics to VSM [14 - 22]. Hence, Faulkner and Badurdeen [23] and Brown et al [24] suggested sustainable VSM (Sus-VSM) to evaluate triple bottom line (TBL) performance of manufacturing and applied to an industry study. The Sus-VSM added environment and social metrics to VSM. However, Faulkner and Badurdeen [23] only focus to identify a general set of metrics that will have broad application across many industries. Further customization may be needed to assess industry specific aspects during application on a case-by-case basis by first identifying key

\footnotetext{
* Corresponding author: srihartini@undip.ac.id
} 
performance drivers for that industry and then selecting relevant metrics to evaluate those aspects.

Goals of this research is to design an analysis technique based on lean and green to achieve sustainable manufacturing, map of wastage and waste from furniture factory (current state mapping) and suggestion strategy to improve production sustainability. This research is very relevant to the problems of Indonesian manufacturing company. Indonesian manufacturing company still has a low level of efficiency, especially small and medium enterprises. A Furniture factory in Semarang has efficiency rate about $50 \%$ [25]. In this case the traditional value stream mapping can determine the source of waste, non-value-added activity, i.e. high setup, inappropriate processes, inventory and defects. The development of jig management information systems can reduce setup time up to $65 \%$ [25]. Redesigning the working environment with $5 \mathrm{~S}$ can reduce the change over time about $41.6 \%$ and can increase the machine capacity [26].

The VSM, however, could not identify the waste (solid, wastewater or emission) in the furniture factory. even though, many forms of non-product output occurs in the furniture industry that may not be realized by the management, such as wood waste from defective product, spraying when doing finishing, excessive use of office paper, glue, water, paint and others. The production of furniture is among the ones that drives global economy : intense environmental degradation and high levels of waste in operational activities and high-volume consumption of raw forest materials [27].

This study developed a sustainable-VSM to evaluate sustainability performance in furniture company after selecting relevant metrics with furniture company. The selecting relevant metrics. The selecting relevant metrics is done based on lean and sustainable manufacturing thinking. It is necessary for furniture company to understand the environmental impacts of their products at each phase of the production processes. Integrating sustainable concept and VSM allows improvement process to focus on specific environmental improvement actions. It also provides benefits in terms of monitoring the environmental impacts during the lean improvement initiatives. To validate the capability of sustainable-VSM, case study was conducted in a furniture company.

\section{Literature review: Value Stream Mapping to enhance sustainability}

Simons and Mason [14] proposed a method called Sustainable Value Stream Mapping (SVSM) as a means to enhancing sustainability in product manufacture by analysing emissions of the greenhouse gas, $\mathrm{CO} 2$, in addition to value-adding time, throughout the value stream. The research used SVSM in a study carried out for the UK Department for Transport in order to model $\mathrm{CO} 2$ emissions from farm gate to retail outlet for alternative distribution scenarios for three supply chains: lettuce, apples and cherries. Norton [13] was extended the SVSM to include additional environmental performance indicators (EPIs) in order to evaluate the occurrence of physical wastes and wasted resources in the manufacture of a specific product or product family, and to attribute those wastes to discrete activities. This extended form of SVSM provides an applied and systematic approach to the improvement of operational efficiency and environmental performance, especially for small companies with limited resources. US Environmental Protection Agency [15] discussed about the toolkit framed by the US EPA's to track the environmental wastes using lean techniques. This tool kit helps in identifying and eliminating environmental wastes by tracking and visualizing environmental metrics namely material and water usage along with conventional VSM metrics. This toolkit fails to include energy consumption metric in VSM. Subsequently, US EPA created another toolkit which adds energy consumption metric with the existing environmental metrics in VSM which helps in tracking energy flow and consumption. However, both the tools fail to include societal metrics and emphasize more on inclusion of environmental and energy consumption metrics in conventional VSM. Torres and Gati [17] developed a managerial tool to align the economical and environmental aspects in production process by mapping strategy. This study was applied in an alcohol and sugar manufacturing industry, but only for water consumption. The tool is called Environmental VSM (EVSM). After the tool development, future development alternatives are discussed. Paju et al. [28] developed a methodology named sustainable manufacturing mapping (SMM) by combining discrete event simulation (DES) and life-cycle analysis (LCA) along with traditional VSM. They also identified sustainable manufacturing indicators and modeled current maps to assess the sustainable performance of manufacturing organizations. It has also been identified that no attempt was made in constructing the desired future state for the current manufacturing system from sustainability viewpoint. Kuriger and Chen [18] modeled an assessment tool integrating environmental and energy metrics with VSM to evaluate the sustainability of manufacturing firms. This tool captures only the energy consumption for processes and fails to capture energy consumed for transportation.

Faulkner and Badurdeen et al. [23] developed a methodology for Sus-VSM to capture economic, environmental, and societal sustainability of manufacturing firms. They also identified suitable metrics and visual symbols to develop Sus-VSM and conducted a study at satellite television dishes manufacturing firm. Brown et al. [24] extended the conventional VSM and incorporated the metrics for sustainability and created a Sus-VSM. The applicability of the model was demonstrated using three case studies and the results are summarized for each case. Folinas et al [22] explored the application of the VSM tool so as to determine the waste that have environmental impact in a specific agrifood supply chain; the production of the canned peach. The main objective of their study is to propose a four-step approach for measuring the environmental performance of supply chains in the food sector based on lean thinking techniques so as to identify sources of waste in the selected supply chain.

Hartini et al. [29] collected some literature on extended VSM to enhance sustainable manufacturing in 
2002 - 2016. It was found that most literature were case study articles, followed by theoretical papers and simulation modeling papers. While, based on three bottom line indicator, that most metrics are environmental, followed by social and then economic metrics. The most of the environment metrics were energy, material and water consumption. Based on the application in the industrial sector, the extended VSMs were applied in the automotive industry, followed by agricultural food and electronic industry. While the sustainable-VSM for the furniture industry has never been applied.

Sustainable-VSM previously developed [23] has a general set of metrics that will have broad application across many industries. However, further customization may be needed to assess specific aspects of furniture company. This study developed sustainable-VSM for furniture company with the specific metrics and relevant with production process of furniture company. And, the study provides insights to practitioners of furniture company to visualize process performance from traditional and environmental.

\section{Design of Sustainable-VSM for Furniture Industry}

\subsection{Design of Metric for Sus-VSM}

Value stream mapping is a system analysis tool designed to find potential waste in the production process. This research develop VSM so that is can analyze the impact of production process towards sustainability.

Design of the metrics in sustainable-VSM for furniture company based on the results of questionnaires from top level of furniture companies (10 companies). Questionnaire based on lean metrics [29] and sustainable manufacturing metrics [30] was prepared using the Likert scale. The selection of metrics is using the level of consensus (cut off value $=0.5$ ) and weighted average (cut off value 4.2). Methodology of metric development for sustainable - VSM for furniture company is shown in the figure 1. Design of metrics in sustainable - VSM for furniture company is shown in Table 1 . Selected metrics for sustainable performance of furniture based on lean manufacturing are time, work in process, cost, defect (economic aspect), material waste, material consumption energy consumption (environment aspect), environment health and safety, physical load index, sickness rate, employee training, hazard material (social aspect). Selected metrics for sustainable performance of furniture based on sustainable manufacturing are revenue, cost (economic aspect), recycling of waste, energy efficiency, material waste and consumption (environment aspect), employee satisfaction, accidents rate (frequency and number), employee health evaluation, local supplier (social aspect). Design of metrics for furniture company based lean and sustainable manufacturing are time, work in process, cost, product defect (economic aspect), energy consumption, material consumption (environment aspect), health rate of employee, safety rate of employee, satisfaction rate of employee, training of employee (social aspect).

Due to revenue is assumed to be represented by cost, so revenue is not selected. Waste treatment is not incorporated in VSM because reuse of wood waste is commonly done in furniture companies. While the chemical waste from finishing process will be done by third party.

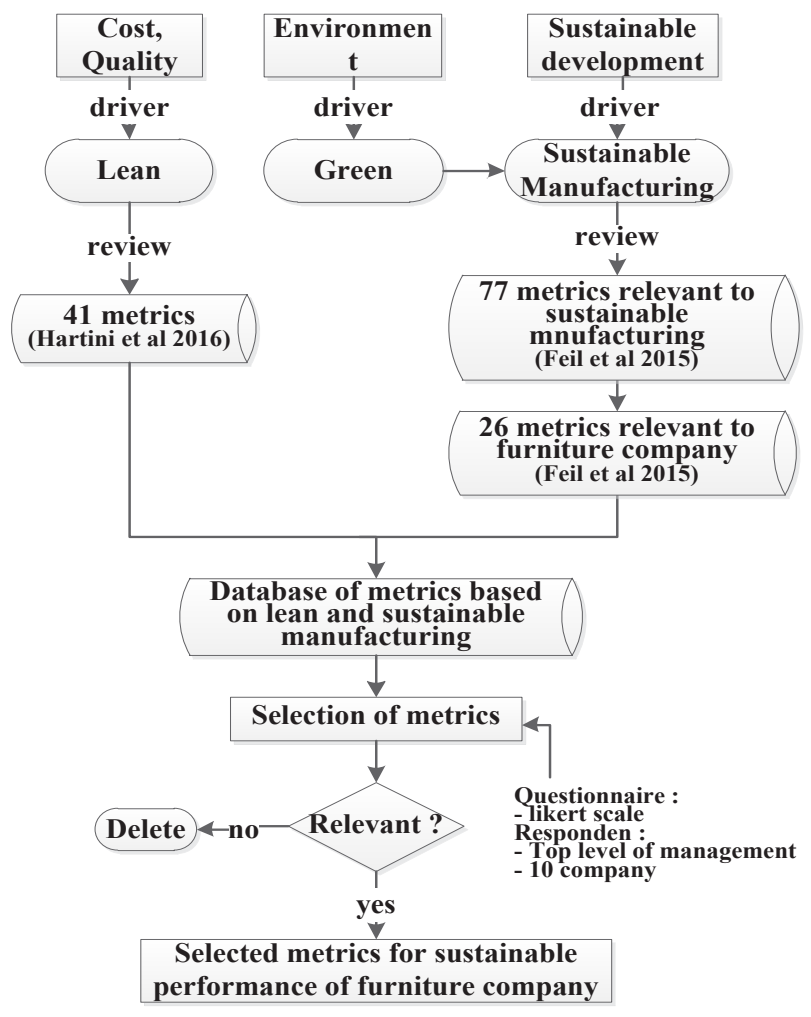

Figure 1 Methodology of metric selection for Sus-VSM in furniture company

\subsection{Design of Sustainable-Value Stream Mapping}

From Table 1, it can be shown that Sustainable-VSM as analysis tool is able to measure economic metric, environment metric, and social metric. With the measured values from the three aspect of sustainability, the sustainability analysis can be done. The proposed sustainable-VSM has multi layer analysis line, including time analysis line for analysis about value-added ratio, material analysis line for analysis about material efficiency, energy analysis line for analysis about energy efficiency, defect analysis line for analysis about quality efficiency, cost analysis line for analysis about cost efficiency and health-safety analysis line for analysis about labour efficiency. Material waste is not include in analysis line because material waste has been incorporated in material analysis line. 
Table 1. Design of metrics in sustainable - VSM for furniture company

\begin{tabular}{|c|c|}
\hline Initial metrics from lean and sustainable manufacturing & Selected metrics \\
\hline $\begin{array}{l}\text { Metrics in value stream mapping for ensure sustainable manufacturing [29] : } \\
\text { Economic : time, work in process, cost, defect } \\
\text { Environment : CO2 emission, energy consumption, hazard waste, material } \\
\text { waste, Packaging waste, waste metal container, water waste, food waste, } \\
\text { material consumption, water consumption } \\
\text { Social : Biodiversity, number of man hour, environment healty safety, absence } \\
\text { day, physical load index, noise, local community, sickness rate, employee } \\
\text { training, hazard material }\end{array}$ & $\begin{array}{l}\text { Economic : time, work in process, cost, } \\
\text { product defect } \\
\text { Environment : energy consumption, material } \\
\text { waste and consumption } \\
\text { Social : environment health \& safety, physical } \\
\text { load index, sickness rate, Employee } \\
\text { training, hazard material }\end{array}$ \\
\hline $\begin{array}{l}\text { Design of metrics in sustainable-value stream mapping for furniture company } \\
\text { based on lean and sustainable manufacturing }\end{array}$ & $\begin{array}{l}\text { Economic : time, work in process, cost, } \\
\text { product defect } \\
\text { Environment : energy consumption, material } \\
\text { waste and material consumption, recycling } \\
\text { of waste } \\
\text { Social : health rate of employee, safety rate of } \\
\text { employee, satisfaction rate of employee, } \\
\text { training of employee }\end{array}$ \\
\hline $\begin{array}{l}\text { Metrics for measuring sustainability in furniture industries [30]: } \\
\text { Environment : Generation of dangerous waste, waste disposal, effluent } \\
\text { treatment, recycling of waste, atmospheric emissions, recycling of products, } \\
\text { reuse of products, renewable energy consumption, efficiency of energy } \\
\text { consumed, consuming renewable materials, adherence to environmental } \\
\text { standards, water consumption } \\
\text { Social : employee satisfaction, employee training and development, serious and } \\
\text { fatal accidents (frequency and number), employee health evaluation, child } \\
\text { labor, complaints of dust, business ethics } \\
\text { Economic : revenue, operating profit, net profit, tax payments, operational } \\
\text { costs, comparison of the wages with the value set by the market, local } \\
\text { suppliers }\end{array}$ & $\begin{array}{l}\text { Environment : recycling of waste, energy } \\
\quad \text { efficiency, material consumption } \\
\text { Economic : revenue, operational costs } \\
\text { Social : employee satisfaction, acccidents rate } \\
\quad \text { (frequency and number), employee health } \\
\text { evaluation, local supplier }\end{array}$ \\
\hline
\end{tabular}
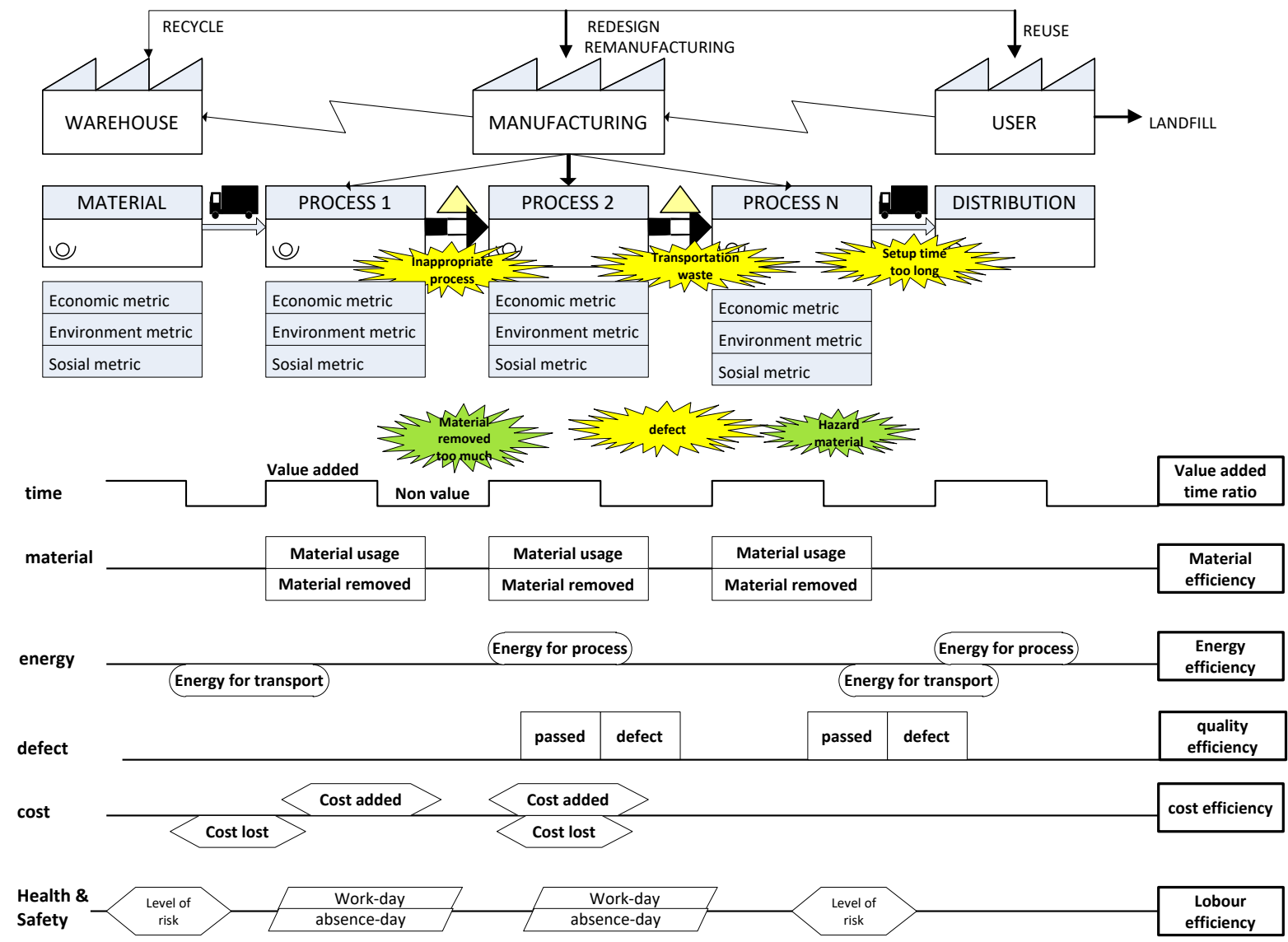

Figure 2. Design of sustainable-value stream mapping that has involved three pillars of sustainable 2 
If the efficiencies of each aspect can be improved then system sustainability can also be improved. Design of sustainable-value stream mapping that has involved three pillars of sustainable manufacturing is shown in Figure 2.

\section{Application in A Furniture Company}

\subsection{Data Collection}

Case study was done at PT X, furniture company in Semarang, Indonesia. The reason to choose this company is that it has relatively high standard product with several product variations. The object are Totem Coat and Hat Stand, because those products were produced in the survey period.

Generally, the production process in PT X are raw material preparation, construction, assembly, finishing, quality control and packaging. The first process is raw material preparation, which is turning wood logs into boards to be processed. Construction process is forming the boards according to the product design. Assembly is the process of combining the various components. Finishing is the last process to finalize the product, e.g. smoothening of the wood surface. After the finishing is done, quality control is done before packaging to ensure that products are in accord to the specifications.

Measurements of production time was designed with 20 observations in each process. Material consumption was calculated using approximated unit of weight by multiplying the wood volume and the density of tamarind wood $(0,45 \mathrm{gr} / \mathrm{cm} 3 \quad$ or $450 \quad \mathrm{Kg} / \mathrm{M} 3)$ (www.fao.org/docrep/w4095e/w4095e0c.htm).

Production of wood waste was calculated by subtracting material input with its output. Energy consumption was approximated by calculating electrical energy needed for production process of Totem Coat and Hat Stand at each machine in kwh. Result of data processing in Fig 3.

\subsection{Discussion}

From the result of sustainable-VSM it can be seen that potential waste from economic and social aspect almost spread in almost all production processes while potential of environmental impact occurs at sawmill and construction process. Waste from economic aspect is marked with yellow spot, environmental aspect with green, and social with blue.

Types of waste in economic aspect includes too much setup and processing time, too many defects and work in process, and machine failure. These can be reduced by improving the work system. Too much unneeded time such as waiting, setup, and transportation time results in large processing time. Old machines and breakdowns are also a problem in production and result in idle time. Careless production process during construction results in out of specification final products. Defects will result in waste of material, workforce, and energy. This will increase the production cost thus reducing profit.

Types of waste in environmental aspect include the high amount of wood waste, especially in sawmill process. Wood consumption efficiency is $145 \mathrm{~kg} / 266 \mathrm{kh}(54,5 \%)$.
The high amount of energy consumption during sawmill process is the most $(60 \%)$, and followed by oven process $(10 \%)$. Reduction in environmental impact can be done by turning wood waste into alternative product that can increase the value. Energy consumption during oven process can be reduced by trying to find another alternative of oven with less energy consumption. Benchmark from other companies suggested, that oven could be operated by burning wood waste that cannot be used anymore. However, burning wood can also produce carbon dioxide emission and has negative impact to the environment. Comparison between using electricity and burning wood waste can be done by looking at the production cost and the emission level.

Social aspect in this research is more focused on the work posture which is not ergonomic. The high amount unergonomic wood lifting and machining may cause muscle strain. This can be reduced by improving the work environment, especially by using aid tools during production process and material handling.

If the potential problems that result in economic, environment, and social aspect can be improved, then sustainability level can also improve.

This research has succeeded in designing analysis tool based on lean and green manufacturing and performing case study in a furniture company. The result is that the developed tools can analyze problems in economic, environment, and social aspects as the basic of improvement.

Up to now, the improvement process still undergone. Once completed, the improvement will provide input for further analysis.

\section{Conclusion}

Improvement design of analysis tool based on lean and sustainable manufacturing has been done and validated by performing case study in a furniture company. Analysis tool is able to identify potential problem in economic, environment, and social aspects which are the pillars of sustainable manufacturing. If these problems can be reduced the sustainability level will improve. Problems in economic aspect include the high amount of process and setup time, amount of defect, breakdown machine and work in process in almost all processes. While in the environmental aspect is the high amount of wood waste during sawmill process and energy during oven process. While in the social aspect is unergonomic the work posture and potential of accident rate still high in sawmill process. 


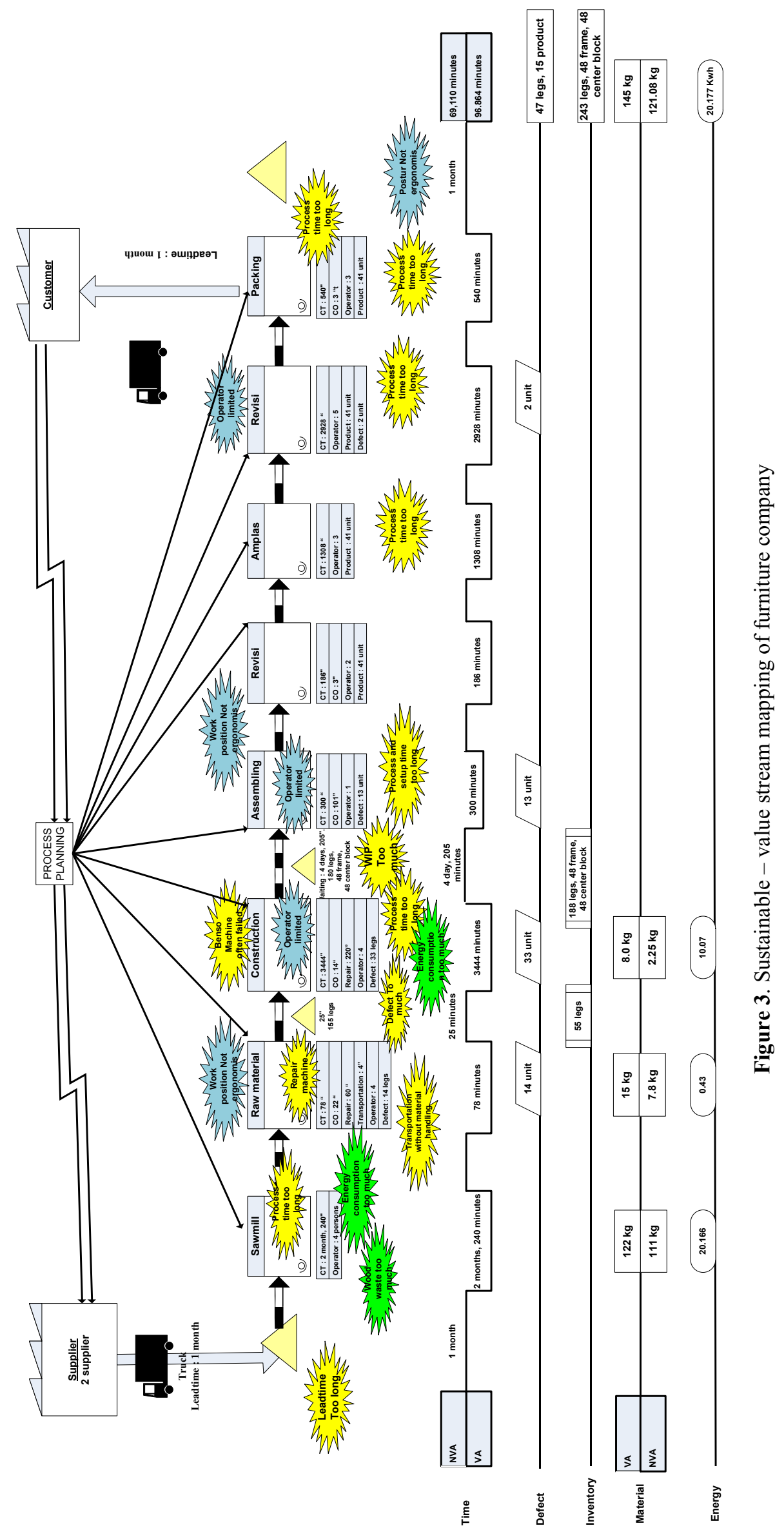


This study successfully developed an analysis tools based on lean and green for evaluate of sustainability performance: sustainable - VSM. If this proposed tools was compared to other sustainable-VSM findings [22-24], this tool involves the relevant metrics with the characteristics of the company under study. The proposed analysis tool involves the level of defect and level of risk that have not been included by other researchers.

However, due to limitations of data access, cost metrics cannot be measured even though they are highly relevant. Suggestions for further research is to do simulation of various strategies that can reduce problems in economic aspect. By doing simulation, a strategy with the highest impact on the improvement of sustainability can be found.

\section{References}

1. J. P. Womack, D. T. Jones, and D. Roos, Bus. Horiz., 35, 81-82 (1992).

2. N. Jasti and R. Kodali, Int. J. Oper. Prod. Manag., 34,1080-1122 (2014).

3. R. R. Fullerton, F. A. Kennedy, and S. K. Widener, J. Oper. Manag., 32, 414-428 (2014).

4. R. R. Fullerton and W. F. Wempe, Int. J. Oper. Prod. Manag., 29, 214-240 (2009).

5. R. Shah and P. T. Ward, J. Oper. Manag., vol. 21,129-149 (2003).

6. A. Chong, H. Cheah, W. P. Wong, and Q. Deng, Proceedings of the 2012 International Conference on Industrial Engineering and Operations Management Istanbul, Turkey, 2012.

7. C. Singh, B., Garg, S.K., Sharma, S.K. and Grewal, Int. J. Lean Six Sigma, 1, 57-168 (2010).

8. R. . Cua, K.O., McKone, K.E. and Schroeder, J. Oper. Manag., vol. 19, 675-694(2001).

9. M. Hallgren and J. Olhager, Int. J. Oper. Prod. Manag., 29, 976-999 (2009).

10. G. Nawanir, L. K. Teong, and S. N. Othman, J. of Manufacturing Tech. Manag., 24, 7(2013).

11. Vinodh, R. B. P. Ruben, and P. Asokan, Clean Technol. Environ. Policy, 18,1(2016).

12. S. Hartini and U. Ciptomulyono, Procedia Manufacturing 4 (Iess, 2015)

13. A. Norton and A. Fearne, Sustainable Value Stream Mapping: A Practical Aid to Sustainable Production. 2007.

14. D. Simons and R. Mason, Ecr, 84-91, 2003.

15. US EPA, http://www.epa.gov/lean/environment/tool kits/energy/index.htm, 2007. .

16. US EPA, The U.S. Environmental Protection Agency (EPA), 2007. .

17. A. S. Torres and A. M. Gati, PICMET '09 - 2009

18. G. W. Kuriger and F. F. Chen, Proceedings of the 2010 Industrial Engineering Research Conference, 2010.
19. M. D. Dadashzadeh and T. J. Wharton, Int. J. Manag. Inf. Syst., 16, 125-136 (2012).

20. H. Li, H. Cao, and X. Pan, Int. J. Comput. Integr. Manuf., 25, 12(2012).

21. D. Folinas, D. Aidonis, G. Malindretos, N. Voulgarakis, and D. Triantafillou, Int. J. Agric. Resour. Gov. Ecol. 10, 129 (2014).

22. D. K. Folinas, D. Aidonis, and P. Karayannakidis, J. Agric. Informatics 6, 24-39 (2015).

23. W. Faulkner and F. Badurdeen, J. Clean. Prod., 85, pp. 8-18 (2014).

24. A. Brown, J. Amundson, and F.Badurdeen, J. Clean. Prod., 1-16 (2014).

25. S. Hartini and I. Rizkiya, Seminar Nasional Teknik Industri dan Manajemen Produksi IV 2009.

26. S. Hartini, Susatyo, and D. Subekti, ApchiErgofuture International Joint Conference 2010

27. J. Gabiati, M. F. Deimling, and R. Barichello, International Administration Conference, 2014.

28. M. Paju, J. Heilala, M. Hentula, A. Heikkila, and B. Johansson, Proceeding of the 2010 Winter Simulation Conference, 2010

29. S. Hartini, U. Ciptomulyono, and M. Anityasari, Annual Conference on Industrial and System Engineering (ACISE), 2016.

30. A. A. Feil, D. M. De Quevedo, and D. Schreiber, Sustain. Prod. Consum.,3, 34-44 (2015). 